\title{
Improving the functioning efficiency of 6-10 kV electrical networks with isolated neutral in conditions of single-phase ground faults
}

\author{
Alexander Nikolaevich Kachanov ${ }^{1, *}$, Vadim Alekseevich Chernyshov ${ }^{1}$, Boris Nikolaevich Meshkov ${ }^{2}$, Marsel Sharifyanovich \\ Garifullin $^{3}$, and Evgeny Alexandrovich Pechagin ${ }^{4}$ \\ ${ }^{1}$ Oryol State University named after I.S. Turgenev, Orel, Russia \\ ${ }^{2}$ LLC "EnerGarant", Orel, Russia \\ ${ }^{3}$ Kazan State Power Engineering University, Kazan, Russia \\ ${ }^{4}$ Tambov State Technical University, Tambov, Russia
}

\begin{abstract}
The main objectives of this publication are: 1) to attract the attention of energy specialists to the problems of reliability and electrical safety of $6-10 \mathrm{kV}$ overhead electrical networks with isolated neutral, operating in conditions of single-phase insulation damage; 2) substantiation of the feasibility of introducing a fundamentally new way to improve the efficiency of $6-10 \mathrm{kV}$ distribution networks, based on the resonanceless limitation of the single-phase ground fault current arising from the breakdown of the insulator and the use of its own infrastructure of the electrical network for remote identification of the place of its occurrence. The expediency of including a nonlinear surge suppressor between the traverse and the grounding outlet of the reinforced concrete support is confirmed by the positive results of experimental studies carried out on the basis of high-voltage testing laboratories of IDGC of Center PJSC - Orelenergo and EnerGarant LLC. The use of deductive analysis allowed the authors to select a reliable and affordable electrical insulating material installed between the support and the traverse, as well as to formulate the main requirements for it, including taking into account weather and climatic factors. The analysis of various methods of transmitting information about the place of occurrence of the insulator damage made it possible to establish the predominant advantage of a wired communication channel using its own $6-10 \mathrm{kV}$ electric network infrastructure. The authors have developed an original circuitry solution that provides remote identification of the insulator damage location using a thyristor shunting the nonlinear surge suppressor, according to a given switching algorithm, and also provides local identification of the insulator breakdown by means of special signaling devices with volatile power supply. It is expected that the proposed method, with relatively low investment, will significantly reduce the level of accidents and electrical hazards in overhead distribution networks of $6-10 \mathrm{kV}$, as well as minimize the costs associated with their operation and undersupply of electrical energy.
\end{abstract}

\section{Introduction}

Low operational reliability of overhead power transmission lines in medium voltage distribution networks of $6-10 \mathrm{kV}$, operating with isolated neutral, is still a very urgent problem for the power systems of many countries and is actively discussed in the scientific community $[1,2]$.

An emergency is the equivalent of turning off an overhead line, stable or eliminated by automatic reclosing. The causes of accidents at $6-10 \mathrm{kV}$ overhead transmission lines can be conditionally classified into three groups [3]:

1. Errors made in the design and construction of 6-10 $\mathrm{kV}$ overhead transmission lines, the result of which is the inability of overhead transmission lines to effectively withstand the unfavorable influence of weather and climatic factors in the region or the negative impact formed by industrial facilities, such as metallurgical enterprises, chemical plants, cement plants and etc.

2. Unsatisfactory quality of operation of $6-10 \mathrm{kV}$ overhead transmission lines, caused by untimely identification and replacement of defective line insulators, as well as unskilled work on clearing the security zone from growing trees. This can also include the unfavorable operating conditions of overhead transmission lines at hazardous production facilities, such as quarries, test sites, etc., the specificity of the operation of which is the cause of power grid damage.

3. Not perfection of standard solutions used in overhead electrical networks $6-10 \mathrm{kV}$. For example, the dielectric and mechanical strength of pin insulators of overhead transmission lines with a voltage of $6-10 \mathrm{kV}$ is

\footnotetext{
*orresponding author: kan@ostu.ru
} 
significantly inferior to the strength of suspension insulators operated on overhead transmission lines with a voltage of $35 \mathrm{kV}$ and above. At the same time, the frequency of occurrence of destructive arc overlaps and the magnitude of the overvoltages formed in them are significantly greater. It is also necessary to pay attention to the fact that the overlapping of pin insulators on 6-10 $\mathrm{kV}$ overhead transmission lines occurs not only with each direct lightning strike, but also with a high degree of probability occurs during induced lightning impulses $[4,5]$. At the same time, the category of reliability of power supply to agro-industrial consumers, in these voltage classes, is often the second or third and does not always provide the possibility of redundancy.

For scientific, engineering and technical workers involved in improving the efficiency and safety of the operation of 6-10 kV overhead networks, the third group of causes of accidents seems to be the most significant, because an obvious solution to the problems of the first and second groups is strict adherence to technical regulations when performing design, construction, installation and repair and maintenance work.

\section{Literature review}

As a result of damage to the insulation of one of the phases, a $6-10 \mathrm{kV}$ distribution network operating in the isolated neutral mode, the magnitude of the single-phase ground fault (SPGF) current will be determined by the capacity of the electrically connected network [1]. However, if, in the event of an SPGF in a network with a compensated neutral, the overvoltage level of the healthy phases of an electrically connected network, relative to the ground, is minimal, then for a network with an isolated neutral, the insulation of healthy phases can experience a significant overvoltage $[6,7,8]$. It should be noted that the type of insulator "SHF $10 \mathrm{G}$ ", which is most used on overhead transmission lines of $6-10 \mathrm{kV}$, even in rainy weather, can withstand voltage up to $42 \mathrm{kV}$ for a long time, and its impulse discharge voltage reaches $100 \mathrm{kV}$. Nevertheless, the statistics of emergency shutdowns indicates that about $23 \%$ of failures of open distribution networks $6-10 \mathrm{kV}$ are associated with the destruction of linear insulation on the supports of overhead transmission lines and transformer substations $[1,9]$.

A rather complex heterogeneous structure, ramification and length of 6-10 kV electrical networks, leads to a high percentage of outages. This is due to the fact that when overcoming various obstacles, in the form of crossings over railway tracks, water obstacles, as well as with multiple connections of overhead transmission lines to transformer substations, various types of switching equipment and cable conductors (inserts) are used with an insufficient and sometimes incompatible level of dielectric strength of insulation. In addition, very long sections of main power lines with a voltage of $6-10 \mathrm{kV}$ combine a huge number of various structural types of supports, with a corresponding variety of electrical insulating equipment. At the same time, the residual margin of safety of the insulation of power grid equipment of 6-10 kV, as a result of a long service life, in many cases exceeding the standard service life, varies in a wide range $[9,10]$.

It is very important to note that overvoltages arising in 6-10 kV electrical networks operating with an isolated neutral lead to damage to the linear insulation, as they are accompanied by extremely dangerous arc SPGF [1, 7].

This emergency situation is also aggravated by the fact that, initiated by low-power capacitive currents, characteristic of an isolated neutral, electric arc discharges, in case of breakdown or overlapping of insulators, in practice lead to voltage surges relative to the ground in undamaged phases of the network.

The processes of overvoltage formation in electrical networks of $6-10 \mathrm{kV}$ with insulated neutral have been devoted to a lot of research works, on the basis of which it follows that the excess voltage on phases with good insulation can reach a critical value - $4.26 \mathrm{Uph}$, where Uph is the phase voltage networks $[7,11]$.

It is also important to state the fact that SPGF, leading to overvoltage, are not the only source of accidents. Capacitive current flowing for a long time through the body of the $6-10 \mathrm{kV}$ overhead power transmission line support, made on a reinforced concrete rack, has an irreversible destructive effect on it. As studies show, the maximum heating temperature of a reinforced concrete rack with a current of SPGF can reach $412{ }^{\circ} \mathrm{C}$, while an increase in the temperature of a reinforced concrete rack by more than $250^{\circ} \mathrm{C}$ leads to a decrease in the adhesion of concrete with smooth profile reinforcement by more than $85 \%$, and with reinforcement with a periodic profile by more than $40 \%$ [12].

Due to the thermal effect on the material of the reinforced concrete support, there is a high probability of its fall. It should be noted that the fall of the support not only leads to an emergency shutdown of the $6-10 \mathrm{kV}$ overhead transmission line, but is often the cause of injury and death of repair personnel when performing climbing work.

In addition to the destabilization of the reliability of a 6-10 kV network with an isolated neutral, due to a chronic decrease in the insulation resource due to SPGF, there is one more, no less important problem, created by SPGF. The flow of the SPGF current, along the reinforced concrete support of the overhead power line, is the cause of industrial and domestic electrical injuries associated with the impact on a person of a step voltage or a touch voltage. There are also known cases of mass death of agricultural cattle grazing in the immediate vicinity of the $6-10 \mathrm{kV}$ overhead power transmission line support with damaged insulation, which forms spreading currents during SPGF.

Based on the foregoing, it follows that scientific research aimed at improving devices and methods for limiting capacitive currents and overvoltages initiated by the SPGF is an urgent task aimed at further developing the theory and practice of improving the efficiency of distribution networks with isolated neutral. 


\section{Materials and methods}

Arc suppression reactors (ASR) are traditionally used to compensate for capacitive currents of SPGF in electrical distribution networks of $6-10 \mathrm{kV}$ with isolated neutral, both in Russia and in the countries of far and near abroad $[11,13]$. These devices create conditions that ensure the rapid self-liquidation of the arc in the place of its origin, with arc SPGF, however, they have the following disadvantages, which significantly hinder their use, namely: high cost of the set of equipment; the need for a radical change in the transformer substations scheme; the complexity of the configuration, taking into account the variability of the parameters of the branched network; problems associated with ensuring the selectivity of the protection action in the case of SPGF, since the magnitude of the leakage current is compensated, as a rule, to a zero value $[14,15,16]$.

A very affordable and effective option for the implementation of blocking capacitive currents and the deprivation of overvoltages arising during SPGF, can serve as a non-resonant current limitation (NRCL) shown in Figure 1. The technical measure consists in the installation, in the grounding gap, of a nonlinear surge suppressor (NSS), long-term withstanding the line voltage of the distribution network [7, 17].

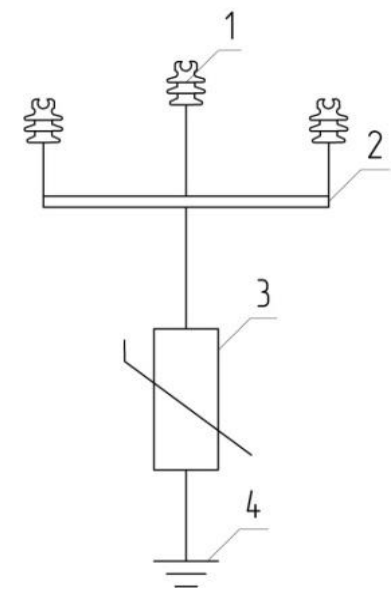

Fig. 1. Schematic electrical diagram of the grounding of a reinforced concrete support with NRCL SPGF: 1 - insulator; 2 - traverse; 3 - nonlinear surge suppressor (NSS); 4 - grounding device.

The introduction of NRCL SPGF is not a high-cost measure, it is characterized by the simplicity of performing electrical work and slightly increases the costs associated with the operation of $6-10 \mathrm{kV}$ overhead transmission lines. Considering the above, it is advisable to use the NRCL SPGF technology on each support of overhead transmission lines in electrical networks of 6$10 \mathrm{kV}$ with an isolated neutral, since it is technically and economically feasible [7].

The choice of a surge arrester as the main element of NRCL SPGF is not accidental, but is due to the nonlinearity of its volt-ampere characteristic (VAC), which allows the grounding device of the $6-10 \mathrm{kV}$ overhead transmission line support to fully preserve its lightning protection functions.
Figure 2 shows the process of phase-to-phase shortcircuit on a reinforced concrete support of a 6-10 kV overhead power transmission line with NRCL SPGF, when a long-spark loop arrester is triggered.

During thunderstorms, when lightning strikes a 6-10 $\mathrm{kV}$ overhead transmission line support or initiates the propagation of an induced overvoltage in the network, the insulation overlaps, at which a high potential appears on the traverse 2 with respect to the ground, exceeding the operating voltage of the NSS 3, as a result of which the current flows unhindered through the grounding device 4 to ground.

It is important to note that in this case, the NSS 3 does not serve to protect against thunderstorm activity, but fulfills another important purpose - it inhibits the appearance of the SPGF in the $6-10 \mathrm{kV}$ electrical network, without interfering with the decrease in the efficiency of the existing grounding device 4.

For the implementation of NRCL SPGF, the condition must be met - the volt-second characteristic (VSC) of insulators 1, must be higher than the VSC of NSS 3, to exclude the likelihood of reverse overlap of adjacent phases in case of breakdown of their insulation [5]. Taking into account the above, we will consider the process of NRCL SPGF functioning in a real electrical network of 6-10 kV with an isolated neutral.

Under normal operating conditions, with the insulators 1 in good condition, on the traverse 2, the potential value can be neglected. In case of damage to any one of the insulators 1 , the potential of the damaged phase is established on the traverse 2 [18]. At the same time, there is practically no current of the SPGF, since NSS 3 has a very high resistance and isolates the traverse 2 from the grounding device 4 . As shown by the studies of the processes occurring during the SPGF, the current value is negligible, since is limited by the resistance of the NSS 3. When lightning strikes the overhead power transmission line, the rising surge front forms a high potential on the traverses of the nearest supports, as a result of which the resistance of the NSS 3 instantly decreases to a minimum value and the pulse discharge current flows through the grounding device 4 to the ground [7].

For practical confirmation of the operability of the NRCL SPGF technology, on the basis of the highvoltage testing laboratory of PJSC IDGC of Center Orelenergo, an experiment was carried out, during which the grounding outlet of the standard reinforced concrete post "SV-110", widely used on 6-10 kV overhead transmission lines, was disconnected from the traverse 2 and connected to it through a NSS 3.

In the process of experimental studies, it was found that the support post, made of reinforced concrete, at the point where the traverse 2 is attached to it, does not have sufficient dielectric strength necessary for the implementation of NRCL SPGF. With a smooth increase in the test voltage, between the traverse 2 and the ground, simulating the developing defect of the insulator, it was found that almost immediately, a current began to flow through the reinforced concrete support post, causing the current protection of the high-voltage test installation to operate. 

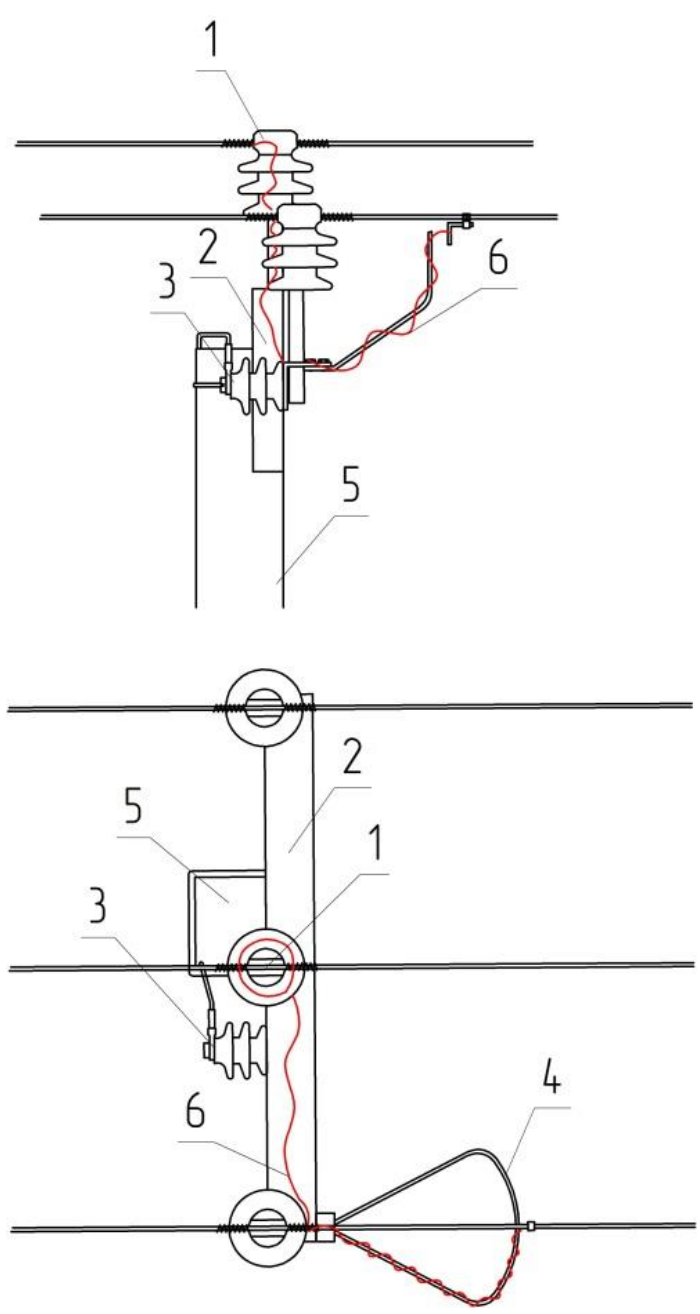

Fig. 2. The process of phase-to-phase short-circuit when the discharger long spark loop is triggered on support with SPGF: 1 - faulty insulator; 2 - traverse; 3 - nonlinear surge suppressor (NSS); 4 - the discharger long spark loop; 5 reinforced concrete rack; 6 - graphical representation of the fault current.

To eliminate this disadvantage, it is necessary to install additional electrical insulating material between the fastening clamp and the reinforced concrete rack [7].

Deductive analysis made it possible to formulate the following basic requirements for the electrical insulating material: high dielectric strength, to ensure long-term withstanding of the line voltage of $6-10 \mathrm{kV}$ overhead power lines; high mechanical strength, to ensure longterm pressure resistance of the fastening clamp holding the crosshead; high resistance to prolonged exposure to sunlight, precipitation, ambient temperature extremes, as well as ease of machining and affordability.

Most varieties of manufactured electrical textolite can be recommended as an electrical insulating material, which meet the requirements listed above.

The main advantages that distinguish textolite favorably from other types of electrical insulating materials include their following technical characteristics: high value of specific volumetric electrical resistance $(1 \bullet 106 \mathrm{Ohm} \bullet \mathrm{m})$; significant specific surface electrical resistance $(1 \cdot 1010 \mathrm{Ohm})$; acceptable level of mechanical strength $(90 \mathrm{MPa})$; the minimum level of water absorption $(0.7 \%)$; wide range of operating temperatures (from - 65 to $1050 \mathrm{C}$ ).

After electrical insulation of the traverse from the support, a second series of experimental studies was carried out using the high-voltage testing laboratory of EnerGarant LLC.

The experiment showed that the installation between the fastening yoke and the pillar of the reinforced concrete support of the textolite, with the corresponding technical characteristics, provides sufficient dielectric strength of the insulation, which is necessary for the successful functioning of NRCL SPGF.

A series of experimental tests made it possible to establish that a smooth increase in the test voltage between the traverse and the ground, simulating the developing defect of the insulator, excluded the operation of the current protection of the testing laboratory, due to the absence of leakage currents through the support post [7].

Figure 3 shows the layout of the NRCL SPGF device on a reinforced concrete support of a $6-10 \mathrm{kV}$ overhead transmission line.
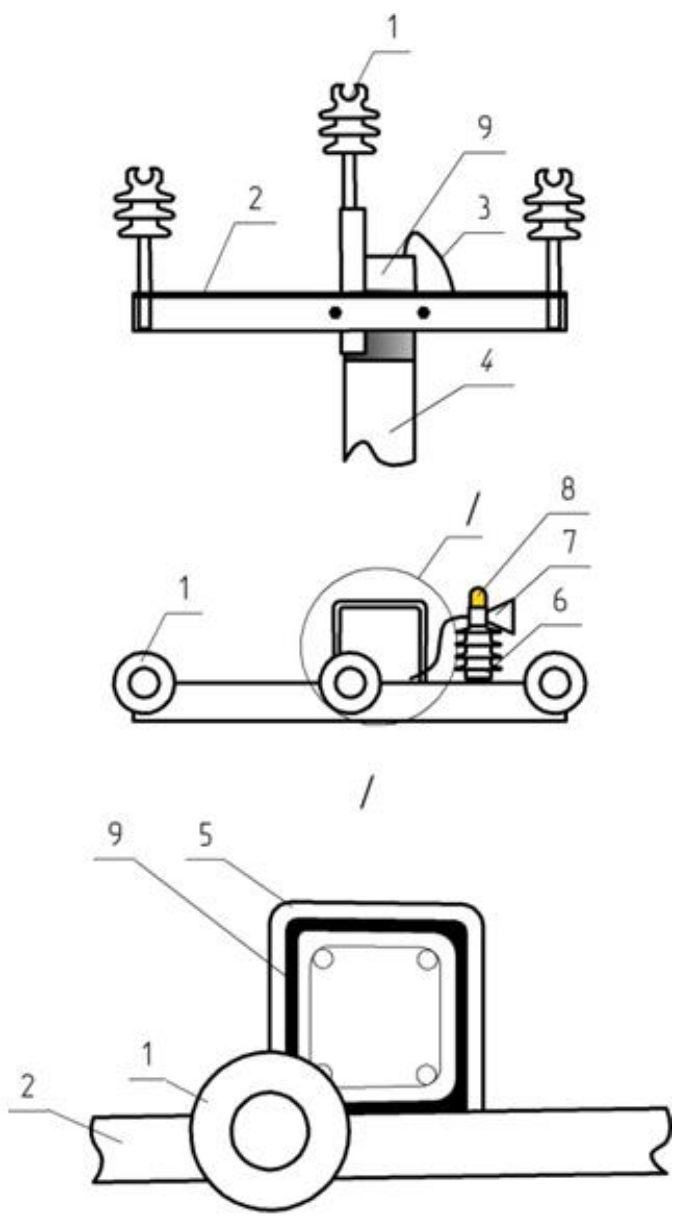

Fig. 3. Layout of the NRCL SPGF device on a support of a 6$10 \mathrm{kV}$ overhead power transmission line: 1 - insulator; 2 traverse; 3 - grounding conductor; 4 - reinforced concrete support post: 5 - fastening clamp; 6 - nonlinear surge suppressor (NSS); 7 - block of sound signaling; 8 - visual signaling unit; 9 - textolite. 


\section{Results}

In order for the repair personnel, when performing emergency recovery work on a functioning $6-10 \mathrm{kV}$ overhead transmission line, to quickly detect a support with a defective insulator, in the absence of an SPGF, each support must be equipped with a warning alarm.

For this, the following elements were introduced into the NRCL SPGF: control and management unit; visualization and sound signaling units (pos. 7, 8 fig. 3), as well as a volatile power supply based on a capacitive voltage divider $[19,20]$.

It should be noted that the sound and visual warning units do not need to generate long-range warning signals, even in the dark, or in conditions of insufficient visibility, since a person or animal approaching a 6-10 $\mathrm{kV}$ overhead line with damaged insulation will be safe. Therefore, a capacitive voltage divider is used as a power source for them, connected in parallel with the nonlinear surge suppressor.

Investing additional funds in NRCL SPGF, will allow to organize remote control of insulators damage in the $6-10 \mathrm{kV}$ overhead electrical network, which allows the personnel of the operational dispatch service to receive and accumulate information about the place of occurrence of the SPGF and cost-effectively plan the logistics of their elimination, by the forces of the operational field teams [21, 22].

The idea for the development of remote monitoring of the damage of insulators on $6-10 \mathrm{kV}$ overhead transmission lines was the results of an experiment carried out on the basis of PJSC IDGC of Center Orelenergo, when the imitation of insulator breakdown, controlled by the presence of current leakage along a reinforced concrete support, triggered the protection of a high-voltage laboratory installation.

In real conditions, upon breakdown of the insulator, the ground acquires the potential of the damaged phase, and the voltage on the undamaged phases relative to the ground increases $\sqrt{3}$ times. An instantaneous change in resistance, between the damaged phase and ground, will abruptly change the voltage between each of the phases and ground, and the measuring instruments will record voltage surges.

Monitoring the voltage of the phases relative to the ground, on the busbars of the $6-10 \mathrm{kV}$ switchgear, allows us to conclude that there is an SPGF in an electrically connected network.

The change in voltage serves as information, the subsequent processing of which will make it possible to determine the place of occurrence of the SPGF in the network [23, 24].

Suppose that on each support of a 6-10 kV overhead transmission line equipped with NRCL SPGF, if its insulator is damaged, an impact will be formed once and for a short time, shunting the NRCL SPGF with an individual sequence of switching. In this case, the pulsating current of the SPGF will cause the appearance of a corresponding sequence of voltage surges between the undamaged phases and the ground, fixing which will make it possible to accurately determine the support with damaged insulation.
Figure 4 shows a single-line diagram of a $10 \mathrm{kV}$ overhead distribution network, which makes it possible to understand the essence of the processes taking place in this network.

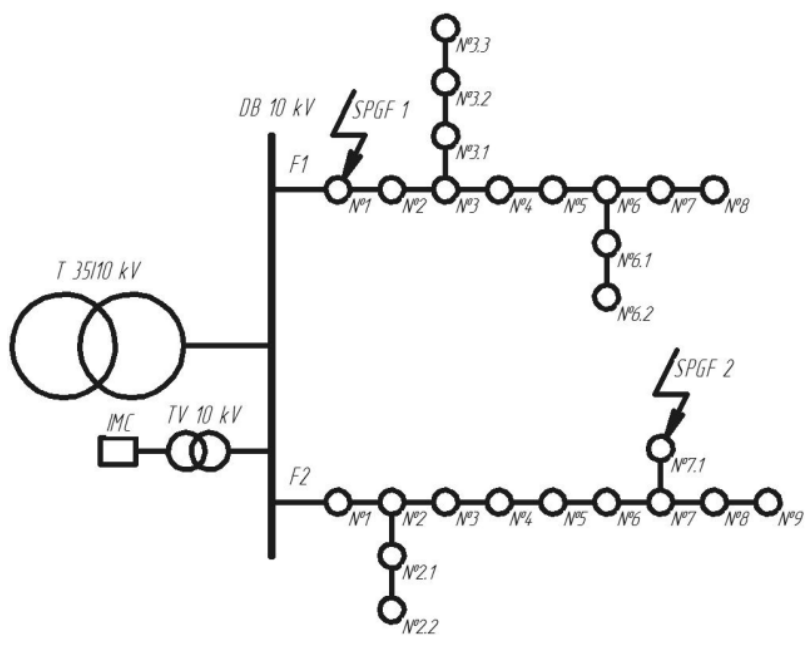

Fig. 4. Scheme of $10 \mathrm{kV}$ overhead distribution network: $\mathrm{T}$ $35 / 10 \mathrm{kV}$ - supply transformer; DB $10 \mathrm{kV}$ - distribution busbar; F1 and F2 - $10 \mathrm{kV}$ overhead transmission lines; №1 №iii - reinforced concrete supports of overhead transmission lines; TV $10 \mathrm{kV}$ - measuring voltage transformer; IMS information measuring complex; SPGF 1 and SPGF 2 - singlephase ground fault points.

The functional diagram of the device that generates the SPGF current inrush is shown in Figure 5. The device consists of the following elements: shunt thyristor "VS"; nonlinear surge suppressor (NSS); monitoring and control unit (CMU), as well as audible (BSS) and visual (VSU) signaling units powered by a capacitive voltage divider [25].

If the dielectric properties (SPGF 1) of one of the insulators (LS1, LS2, LS3) of a support, for example, support No. 1 (feeder No. 1), are violated on its traverse, the control and monitoring unit (CMU) will fix the presence of voltage and issue an individual control signal for short-term commutation thyristor VS, bypassing NSS. 


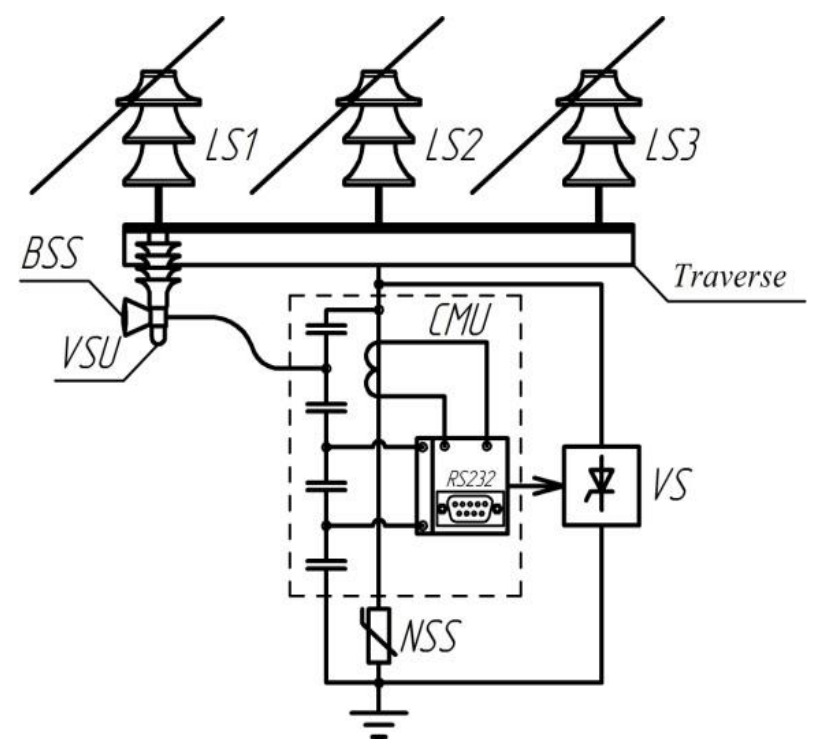

Fig. 5. Functional diagram of a device that generates inrush currents SPGF.

Let us briefly consider the principle of operation of the device that generates inrush current SPGF. When the VS thyristor shunts the NSS nonlinear surge suppressor when opened, the voltage between the ground and the undamaged phases increases in proportion to the degree of insulation damage. When the thyristor VS is closed, the circuit returns to its original state, and the SPGF current decreases to zero. In this case, the voltage on the undamaged phases, relative to earth, will decrease to the nominal level. The time intervals of alternating combinations of opening and closing shunt thyristors are programmed individually for each CMU and are not repeated on any of the $6-10 \mathrm{kV}$ overhead transmission line supports [25].

As an example, let us consider one of the possible switching algorithms for a shunt thyristor VS, which supplies the SPGF current bypassing the NSS, which makes it possible to remotely identify the location of the insulation fault. At the beginning, an inrush current SPGF is formed, with a duration in seconds corresponding to the number of the feeder. Then a pause is formed with a duration in seconds corresponding to the branch number. Then an inrush current of the SPGF is formed with a duration in seconds, which characterizes the degree of damage to the insulator. After that, a pause is formed with a duration in seconds corresponding to the number of the support with damaged insulation and, at the end, an inrush current of the SPGF is formed again, with a duration in seconds corresponding to the number of the feeder. If SPGF 2 appears on support No. 7.1 (feeder No. 2, branch No. 7), its CMU will generate the following sequence of current surges SPGF 2: pulse - 2 seconds; pause - 7 seconds; impulse - 3 seconds; pause - 1 second; impulse - 2 sec. An information-measuring complex (IMC), connected to the buses of a switchgear DB $10 \mathrm{kV}$, records the dynamics of voltage changes between undamaged phases and ground and determines the number of the feeder, the number of the connection and the number of the support with damaged insulation, and also provides information on the degree of damage to the insulator [25].

\section{Discussions}

The proposed technical solution, upon first acquaintance with it, may cause confusion among specialists who design and operate networks with a voltage of $6-10 \mathrm{kV}$, because the presence of a surge arrester in the circuit of the grounding device contradicts paragraph 1.7.139 [26]. However, upon a more detailed examination of the proposed technical solution and analysis of the norms, its legitimacy is beyond doubt, since the requirements of paragraph 1.7.139 [26] apply to the use of protective earthing conductors. According to clause 1.7.29 [26]: it follows that "Protective grounding is a grounding made for the purpose of electrical safety." The method of grounding the supports of $6-10 \mathrm{kV}$ overhead transmission lines used in this case is performed not in order to ensure electrical safety, but in order to protect against atmospheric electricity. And the presence of grounding devices on overhead transmission lines is the reason for their increased electrical hazard due to the appearance of hazardous zones with different potential levels around the supports of $6-10 \mathrm{kV}$ overhead transmission lines.

It should be noted that the large-scale implementation of the NRCL SPGF technology will require a revision of the concepts of relay protection against SPGF in $6-10 \mathrm{kV}$ networks with isolated neutral, acting on the shutdown and signal, since the limitation of the SPGF current excludes the possibility of their use [27]. Despite the fact that with NRCL SPGF, the appearance of the potential of one of the phases on the traverse of the overhead transmission line support increases the risk of a phase-to-phase short circuit (in the event of insulation overlap or the operation of the discharger long spark loop on any of the adjacent phases), the total number of overhead transmission line failures will significantly decrease due to a decrease in the number of overvoltage in a $6-10 \mathrm{kV}$ network. At the same time, the triggering of the maximum current protection is possible only when the second phase is switched to the traverse of the 6-10 $\mathrm{kV}$ overhead power transmission line support with a damaged insulator, and not in any other place of the electrically connected network, as if this happened without NRCL SPGF [7, 11].

Most of the modern devices and methods for identifying SPGF in electrical networks $6-10 \mathrm{kV}$ with isolated neutral, are characterized by low accuracy of operation, are expensive and can significantly increase the cost of operating a $6-10 \mathrm{kV}$ network [28, 29]. In addition, on most 6-10 kV overhead transmission lines, the organization of modern communication channels, such as: GPRS, HDSL, 3G, Wi-Fi, fiber-optic lines, etc., is not economically feasible, because this will also require costly design changes $[30,31]$. At the same time, the introduction into the maintenance system of 6$10 \mathrm{kV}$ overhead transmission lines, third-party organizations providing the listed communication channels, significantly complicates the structure of 
operation of the 6-10 kV electrical distribution network. The use of our own 6-10 kV network infrastructure as a channel for transmitting information about the SPGF, serviced on our own, will provide the power grid enterprise with cybersecurity $[32,33]$, and will also make it independent of telecommunication service providers, which is especially important in an unstable economy [22].

\section{Conclusions}

It is not by chance that overhead electrical networks of $6-10 \mathrm{kV}$ with insulated neutral are the longest. The possibility of operation of a $6-10 \mathrm{kV}$ overhead transmission line with SPGF allows until the last moment to maintain an uninterrupted power supply to remote agro-industrial consumers, until the on-site team finds the place of insulation damage and starts to eliminate it. The recent, hastily made decision on selective shutdown of the SPGF can hardly be considered appropriate in the conditions of chronic wear of $6-10 \mathrm{kV}$ networks. This statement is based on the fact that the safe identification of the SPGF, when the voltage is removed from the overhead transmission line, requires significantly more time and material and labor resources, and also increases the undersupply of electrical energy. The introduction of NRCL SPGF devices, signaling the breakdown of the insulator at the site, as well as providing remote transmission of information to the dispatcher about the place of occurrence of the SPGF, will create favorable conditions for the operation of the linear insulation of $6-10 \mathrm{kV}$ overhead power lines, minimize the level of industrial and household electrical injuries, and will also provide savings in search transport and labor resources. At the same time, the synergy of the listed positive factors will ensure the high efficiency of functioning of $6-10 \mathrm{kV}$ air distribution networks with isolated neutral in the conditions of SPGF.

\section{References}

1. A.N. Kachanov, V.A. Chernyshov, Prognozirovaniye veroyatnosti vozniknoveniya odnofaznykh zamykaniy na zemlyu $\mathrm{V}$ raspredelitel'nykh setyakh $10 \mathrm{kV} \quad \mathrm{s}$ uchetom pogodno-klimaticheskikh faktorov, Promyshlennaya energetika, 10, 10-17 (2020)

2. A.M. Yershov, A. Khlopova, A. Sidorov, Rezul'taty issledovaniya rezhimov elektrosetevogo khozyaystva pri obryve faznogo provoda VL 6-10 kV, Mezhdunarodnaya konferentsiya po promyshlennomu proyektirovaniyu, primeneniyu i proizvodstvu (ICIEAM), 2017, Sankt-Peterburg, 8076280 (2017)

3. V. Chzhan, M. Khe, Dzh. Ren, YU. Ven', Z. Chzhan, Z. Pu , R. Chzhan, Opredeleniye mesta povrezhdeniya SLG (odna liniya-zemlya) V NUGS (sistema s neeffektivnym zazemleniyem neytrali), Set' konferentsiy MATEC,
Mezhdunarodnaya konferentsiya po elektrotekhnike, kontrolyu i robototekhnike (EECR 2018), 160 (01009) (2018) DOI: 10.1051 /matecconf/201816001009

4. D.M. Yuditskiy, A.Ye. Usachev, Sravnitel'naya otsenka doli udarov molniy $\mathrm{v}$ opory i verkhniy faznyy provod $\mathrm{V}$ prolete $\mathrm{VL}$ bez molniyezashchitnogo trosa, Izvestiya vysshikh uchebnykh zavedeniy, Problemy energetiki, 20 (3-4), 3-10 (2018) DOI: 10.30724/1998-99032018-20-3-4-3-10

5. D.A. Glukhov, E.F. Khakimzyanov, D.Ye. Titov, G.G. Ugarov, R.G. Mustafin, Analiz riska otkaza lineynoy izolyatsii putem otsenki poperechnoy provodimosti vozdushnykh liniy elektroperedach po dannym sinkhronizirovannykh vektornykh izmereniy, Izvestiya vysshikh uchebnykh zavedeniy, Problemy energetiki, 20 (11-12), 3445 (2018) DOI: 10.30724/1998-9903-2018-2011-12-34-45

6. F. Pito, K. Venkataraman, N. Vasilevskiy, K.P. Teon, Vattmetricheskaya zashchita ot zamykaniy na zemlyu - innovatsiya dlya kompensirovannykh raspredelitel'nykh setey, 23-ya Mezhdunarodnaya konferentsiya po raspredeleniyu elektroenergii, Lion, 0963 (2015)

7. Ye.A. Pechagin, V.A. Chernyshov, B.N. Meshkov, Al'ternativnyy variant kompensatsii yemkostnykh tokov dlya vozdushnykh liniy elektroperedachi napryazheniyem 6-10 kV, Vestnik tambovskogo gosudarstvennogo tekhnicheskogo universiteta, 22 (4), 581-587 (2016)

8. V.Ye. Kachesov, R.A. Finashin, L.I. Tolstobrova, Impul'sno-rezistivnoye zazemleniye neytrali trekhfaznoy elektroseti i yeye fizicheskaya model', Aktual'nyye problemy elektronnogo priborostroyeniya (APEIE - 2018), 14 mezhdunar. nauch.-tekhn. konf., Novosibirsk, 2-6 October 2018, Novosibirsk: Izd-vo NGTU, 1 (2), 259-263 (2018)

9. D.A. Polyakov, G.A. Koshchuk, K.I. Nikitin, Opredeleniye ostatochnogo resursa liniy elektroperedachi $\mathrm{s}$ izolyatsiyey iz sshitogo polietilena, Rossiyskaya elektrotekhnika, 88 (5), 271-273 (2017)

10. K. Chen, K. Khuang, Dzh. Khe, Obnaruzheniye, klassifikatsiya i lokalizatsiya neispravnostey dlya liniy elektroperedachi i raspredelitel'nykh sistem: obzor metodov, 1 (1), 25-33 (2016)

11. S.V. Kuz'min, Ye.V. Umetskaya, A.A. Zavalov, Vliyaniye kachestva elektroenergii na velichinu kommutatsionnykh perenapryazheniy $\mathrm{v}$ setyakh 6-10 kV, Mezhdunarodnaya mul'tikonferentsiya po promyshlennoy inzhenerii i sovremennym tekhnologiyam, FarEastCon (2020) DOI: 10.1109/FarEastCon50210.2020.9271527

12. D.A. Polyakov, D.A. Yurchuk, K.I. Nikitin, Tsifrovoy izmeritel' temperatury polietilenovoy 
izolyatsii, Mezhdunarodnaya sibirskaya konferentsiya IEEE po upravleniyu i kommunikatsiyam, SIBCON 2015 - Trudy, Omsk (2015)

13. K. Figeyredo, G. Mello, M. Sil'veyra, Rezonansnoye zazemleniye, primenyayemoye $\mathrm{v}$ Brazilii, 24-ya Mezhdunarodnaya konferentsiya po raspredeleniyu elektroenergii, Glazgo, 1250 (2017)

14. D.G. Safonov, S.S. Girshin, V. Goryunov, Ye.A. Kuznetsov, Ye. Petrova, Analiz asimmetrichnykh rezhimov $\mathrm{v}$ elektricheskikh setyakh srednego napryazheniya s kompensirovannoy neytral'yu, 3ya Mezhdunarodnaya konferentsiya po proizvodstvu i promyshlennym tekhnologiyam, Stambul, 25-27 May 2016, 70 (2016) DOI: $10.1051 /$ matecconf $/ 20167010008$

15. D.G. Safonov, S.S. Girshin, V. Goryunov, Ye.A. Kuznetsov, Ye. Petrova, Raschet ustanovivshegosya rezhima radiosistemy moshchnost'yu $35 \quad \mathrm{kVt} \quad \mathrm{s}$ dugogasyashchimi katushkami $\mathrm{s}$ uchetom asimmetrii liniy elektroperedachi, 16-ya Mezhdunarodnaya konferentsiya IEEE po okruzhayushchey srede i elektrotekhnike, Florentsiya, 7-10 June 2016, 1-5 (2016) DOI: 10.1109/EEEIC.2016.7555455

16. G. Draml, P. Shegner, L. Fikert, M. Shlemmer, Preimushchestva novogo sochetaniya katushki Petersena i neispravnogo fazovogo zazemleniya, 24-ya Mezhdunarodnaya konferentsiya po raspredeleniyu elektroenergii, Glazgo, 1450 (2017)

17. B.N. Meshkov, V.A. Chernyshov, Sposob ogranicheniya toka odnofaznogo zamykaniya na zemlyu dlya vozdushnoy linii elektroperedachi $\mathrm{v}$ seti s izolirovannoy neytral'yu, Patent RF, zayavitel' i patentoobladatel' FGBOU VPO Orel GAU. 2014116282/07, zayavl. 22 April 2014, opubl. 27 Febrary 2016, 6, 2576017, 5

18. A.V. Golenishchev-Kutuzov, V.A. GolenishchevKutuzov, D.A. Ivanov, G.D. Mardanov, Distantsionnyy kontrol' tekhnicheskogo sostoyaniya farforovykh vysokovol'tnykh izolyatorov, Izvestiya vysshikh uchebnykh zavedeniy, Problemy energetiki, 20 (3-4), 99-107 (2018) DOI: 10.30724/1998-9903-2018-20-3-499-107

19. D.K. Zaripov, R. Balobanov, Indikator defekta vysokovol'tnoy izolyatsionnoy konstruktsii, Rossiyskaya elektrotekhnika, 87 (6), 311-315 (2016)

20. YU.F. Korolyuk, N.S. Buryanina, Ye.V. Lesnykh, Ustroystvo otbora moshchnosti ot linii elektroperedachi, Patent RF, zayaviteli i patentoobladateli 2013129389/07, zayavl. 26 June 2013, opubl. 10 August 2015, Byul. 22, 2558690, 5

21. S. Ravlich, A. Marushich, YA. Gavelka, Usovershenstvovannyy metod obnaruzheniya povrezhdeniy s vysokim impedansom $\mathrm{v}$ setyakh srednego napryazheniya, TechnicalGazette, 24 (2), 391-396 (2017) DOI: $10.17559 / \mathrm{TV}-$ 20151012082303

22. G.S. Bokov, Tekhnicheskoye perevooruzheniye rossiyskikh elektricheskikh setey, Skol'ko eto mozhet stoit'?, Novosti elektrotekhniki, 2 (14) (2002)

23. K. Dzenis, A. Yurish, Tochnaya lokalizatsiya zamykaniy na zemlyu $\mathrm{v}$ setyakh $\mathrm{s}$ nezazemlennym zazemleniyem na osnove analiza perekhodnykh protsessov, 24-ya Mezhdunarodnaya konferentsiya po raspredeleniyu elektroenergii, Glazgo, $\mathbf{0 7 5 9}$ (2017)

24. SH.S. Saydaliyev, R.G. Valeyev, Modelirovaniye neytralizuyushchey sistemy $\mathrm{v}$ srede Matlab + Simulink dlya usloviy issledovaniya elektrobezopasnosti, 18 2-ya Mezhdunarodnaya konferentsiya po promyshlennomu inzhiniringu (MKPP-2016), Chelyabinsk, Rossiya, 19-20 May 2016, IEEE Conf. Opubl. (2016) DOI: 10.1109/ICIEAM.2016.7911693

25. V.V.A. Chernyshov, B.N. Meshkov, Sposob opredeleniya mesta vozniknoveniya odnofaznogo zamykaniya na zemlyu dlya vozdushnykh liniyyeredachi $\mathrm{V}$ setyakh $\mathrm{S}$ izolirovannoy neytral'yu, Patent RF, zayavitel' i patentoobladatel' FGBOU VPO Orel GAU, 2013112911/07, zayavl. 22 March 2013, opubl. 20 December 2014, Byul. 35, 2536168, 5

26. Pravila ustroystva elektroustanovok, 7-ye i 6-ye izdaniya (SPb.: Izdatel'stvo DEAN, 1172, 2017)

27. N.I. Voropay, D.N. Yefimov, I.N. Kolosok, V.G. Kurbatskiy, A.M. Glazunova, Ye. Korkina, A.B. Osak, N.V. Tomin, D.A. Panasetskiy, Intellektual'nyye tekhnologii $\mathrm{v}$ protivoavariynom upravlenii yedinoy energosistemoy Rossii, IEEE Transactions on Smart Grid, 4 (3), 1732-1740 (2013) DOI: 10.1109 / TSG.2013.2251684

28. V.A. Chernyshov, A.Ye. Semenov, R.P. Belikov, V.Ye. Bol'shev, M. Yasinskiy, M.S. Garifullin, Sposob uvelicheniya avtonomnosti pilotirovaniya drona pri kontrole tekhnicheskogo sostoyaniya VL 6-10 kV, Set' konferentsiy E3S, Mezhdunarodnaya nauchno-tekhnicheskaya konferentsiya «Umnyye energeticheskiye sistemy» (SES 2019), Dokument 02010 (2019)

29. D. Roberts, D. Gektor, Dzh. Altuve, D. Datsin Khou, Obzor metodov zashchity ot zamykaniy na zemlyu dlya zazemlennykh, nezazemlennykh i kompensirovannykh raspredelitel'nykh system, 140 (2004)

30. A. Yershov, A. Khlopova, A. Sidorov, Rasshireniye funktsiy mikroprotsessornykh schetchikov elektroenergii dlya obnaruzheniya obryva faznykh provodov VL $10 \mathrm{kV}$, Global'naya konferentsiya po umnoy industrii 2018 (GloSIC), 
Chelyabinsk, $\mathbf{8 5 7 0 0 9 5}$ (2018) DOI:

10.1109/GloSIC.2018.8570095

31. I.N. Lizunov, A.N. Vasev, R.SH. Misbakhov, V.V. Fedotov, E.A. Khuziakhmetova, Tekhnologii peredachi dannykh v sovremennykh sistemakh releynoy zashchity i avtomatiki i ikh pokazateli kachestva, Izvestiya vysshikh uchebnykh zavedeniy, Problemy energetiki, 19 (1-2), 52-63 (2017) DOI: 10.30724/1998-99032017-19-1-2-52-63

32. L.V. Massel', N.I. Voropay, S.M. Senderov, A.G. Massel', Kiberopasnost' kak odna iz strategicheskikh ugroz energeticheskoy bezopasnosti Rossii, Voprosy kiberbezopasnosti, 4 (17), 2-10 (2016) DOI: 10.21681/2311-34562016-4-2-10

33. Dzh.L. Blekbern, Zashchitnyye rele: printsipy $i$ primeneniye (Taylor \& Francis Group, LLC, 638, 2006) 